\title{
PERSISTENCE OF SOME HERBICIDES USED FOR WEED CONTROL IN MAIZE
}

\author{
A. RAHMAN, B. BURNEY and B. E. MANSON \\ Soil and Field Research Organisation, \\ Ruakura Agricultural Research Centre, \\ $M A F$, Hamilton \\ Summary
}

In two field trials maize was treated with four herbicides and soil samples were collected from the top $7.5 \mathrm{~cm}$ depth at monthly intervals for bioassay of toxic residues in the glasshouse. From equal rates of application atrazine and metolachlor were considerably more persistent in the soil than cyanazine and alachlor respectively in both years of study. Residual activity of the proprietary mixture of atrazine and metolachlor was proportional to the rate of metolachlor when German millet (Setaria italica) was the bioassay species. However, when oats (Avena sativa), a species susceptible to both herbicides, were used for bioassay, the residual toxicity of the mixture was statistically similar to that recorded from the same rate of two herbicides applied separately.

\section{INTRODUCTION}

One of the commonly used herbicide combinations for weed control in maize is that of atrazine and alachlor which has generally provided satisfactory results. Occasionally problems have been encountered with both these herbicides. Atrazine residues may sometimes be toxic to susceptible species in the rotation on lower organic matter soils, especially if these crops follow maize in the autumn (Naish and Forgie 1976; Rahman and Brown 1977). Alachlor is known to be moisture sensitive and, where rainfall is low or variable in early summer, sometimes disappointing results have been obtained with this herbicide.

Due to these disadvantages alternative herbicides are being investigated to replace or supplement the atrazine-alachlor combination. Cyanazine is reported to have shorter residual activity than atrazine (Burnside 1976; Haddow 1977; Sirons et al 1973) but controls a similar spectrum of weeds with higher activity against annual grasses. A recently developed herbicide, metolachlor, has been reported to be less dependent on rainfall and persist in the soil longer than alachlor (Rowe et al 1976). The present work was designed to compare the residual activity of these four herbicides in the soil.

\section{MATERIALS AND METHODS}

This study included two field trials located within $5 \mathrm{~km}$ of each other near Hamilton. The 1976-77 trial was on a Horotiu sandy loam soil and the 1977-78 trial was conducted on a Hamilton clay loam soil. Some chemical and physical properties of the top $10 \mathrm{~cm}$ of two soils are listed in Table 1. Techniques for determining these properties have been described previously (Rahman 1977).

Proc. 31 st N.Z. Weed and Pest Control Conf. 
Crop Weeds

TABLE 1: Some chemical and physical properties of the soils at the two trial sites.

\begin{tabular}{|c|c|c|c|c|c|c|c|}
\hline Soil Type & $\begin{array}{l}\text { Organic } \\
(\%)\end{array}$ & (t/ha) & $\begin{array}{c}\text { Sand } \\
(\%)\end{array}$ & $\begin{array}{l}\text { Clay } \\
(\%)\end{array}$ & $\begin{array}{c}\text { C.E.C. } \\
(\mathrm{mEq} / 100 \mathrm{~g})\end{array}$ & $\mathrm{pH}$ & $\begin{array}{c}\text { Field } \\
\text { capacity } \\
(\%)\end{array}$ \\
\hline $\begin{array}{l}\text { Horotiu } \\
\text { Hamilton }\end{array}$ & $\begin{array}{r}11.7 \\
8.4\end{array}$ & $\begin{array}{l}82.8 \\
67.1\end{array}$ & $\begin{array}{l}58 \\
27\end{array}$ & $\begin{array}{l}15 \\
31\end{array}$ & $\begin{array}{l}31.1 \\
29.0\end{array}$ & $\begin{array}{l}5.4 \\
5.5\end{array}$ & $\begin{array}{l}42.5 \\
36.1\end{array}$ \\
\hline
\end{tabular}

Three rates of each herbicide were surface applied as pre-emergence treatments in a spray volume of 350 litres/ha at $245 \mathrm{kPa}$. In the 1977-78 trial two rates of a propriety mixture of atrazine and metolachlor were also included in the trial. Individual plots were $10 \times 3.75 \mathrm{~m}$ in which 5 rows of maize cv 'PX 610' were planted $75 \mathrm{~cm}$ apart with a precision drill. Treatments were arranged in a randomised block design with four replications.

Soil samples for residue analysis were collected at monthly intervals from the date of spraying until residues fell below the level of detection. Samples were collected to a depth of $7.5 \mathrm{~cm}$ with a $7-\mathrm{cm}$ diameter sampling tube. They were bioassayed in a glasshouse using the procedure described by Rahman and Cox (1975). The bioassay species used for measuring the herbicidal activity were turnips (Brassica rapa cv 'Green globe') and oats cv 'Mapua' for atrazine and cyanazine and German millet and oats for alachlor and metolachlor.

\section{RESULTS AND DISCUSSION}

Data from 'standards' established for each herbicide by employing a range of dosages are presented in Table 2. The two species used for bioassay of each herbicide gave comparable results but turnips did not grow satisfactorily at some times of the year and oats were not as sensitive as German millet to acetanilide herbicides. Cyanazine had greater toxic effect on oats than atrazine at identical rates. Similarly metolachlor was much more toxic to German millet than alachlor, which confirms its high effectiveness on commonly occurring grass weeds observed by other workers (Rowe et al 1976).

TABLE 2: Effect of herbicides on dry shoot weight of bioassay species in the glasshouse (data expressed as \% of control).

\begin{tabular}{cccccc}
\hline \multirow{2}{*}{$\begin{array}{c}\text { Rate } \\
(\mathrm{ppmw})\end{array}$} & , & \multicolumn{2}{c}{ German millet } \\
\cline { 3 - 5 } \cline { 5 - 6 } & atrazine & cyanazine & & alachlor & metolachlor \\
\hline 0 & $100 \mathrm{a}$ & $100 \mathrm{a}$ & $100 \mathrm{a}$ & $100 \mathrm{a}$ \\
0.1 & $102 \mathrm{a}$ & $94 \mathrm{a}$ & $101 \mathrm{a}$ & $89 \mathrm{a}$ \\
0.2 & $81 \mathrm{ab}$ & $67 \mathrm{~b}$ & $94 \mathrm{a}$ & $48 \mathrm{~b}$ \\
0.3 & $48 \mathrm{c}$ & $28 \mathrm{c}$ & $59 \mathrm{~b}$ & $26 \mathrm{c}$ \\
0.4 & $23 \mathrm{~d}$ & $4 \mathrm{~d}$ & & $42 \mathrm{c}$ & $16 \mathrm{~cd}$ \\
0.5 & $2 \mathrm{e}$ & 0 & $34 \mathrm{~cd}$ & $5 \mathrm{~d}$ \\
0.6 & 0 & 0 & $21 \mathrm{~d}$ & 0 \\
\hline
\end{tabular}




\section{Crop Weeds}

Bioassay data on residual activity of herbicides at monthly intervals which are the mean figures of the two trials, are presented in Tables 3 and 4. These clearly show that atrazine had much longer persistence than cyanazine from the same rate of application (Table 3). At the rates recommended for use in maize (around $1.5 \mathrm{~kg} / \mathrm{ha}$ ) cyanazine's activity would fall below phytotoxic levels in under 3 months whereas atrazine would have toxic residues in the soil for up to 5-6 months.

TABLE 3: Residual activity of atrazine and cyanazine in soil samples collected at monthly intervals (DM of oats as \% of control).

\begin{tabular}{llrrrrrrrr}
\hline $\begin{array}{c}\text { Rate } \\
(\mathrm{kg} / \mathrm{ha})\end{array}$ & \multicolumn{8}{c}{ months after application* } \\
\cline { 2 - 8 } & 1 & 2 & 3 & 4 & 5 & 6 & 7 & 9 \\
\hline atrazine & 0 & 36 & 74 & & & & & \\
1 & 0 & 4 & 28 & 43 & 68 & 77 & & \\
2 & 0 & 0 & 0 & 18 & 39 & 61 & 73 & \\
3 & & & & & & & & & \\
cyanazine & 63 & & & & & & & \\
1 & 50 & 67 & & & & & & \\
2 & 13 & 41 & 76 & & & & & \\
3 & & & & & & & \\
\hline
\end{tabular}

* Figures in this table are all significantly different from their respective controls $(=100), P<0.05$, pooled $S E \pm 6.1$. Blank spaces indicate that no significant differences were recorded in that month.

When applied at comparable initial rates, metolachlor persisted in phytotoxic amounts in the soil much longer than alachlor (Table 4). At recommended rates of application (around $3 \mathrm{~kg} / \mathrm{ha}$ ) metolachlor could be toxic to many germinating grass weeds for 4-5 months in most soils, which is a little longer than is the case with alachlor.

TABLE 4: Residual activity of alachlor and metolachlor in soil samples collected at monthly intervals (DM of German millet as \% of control).

\begin{tabular}{lrrrrrrrr}
\hline \multirow{2}{*}{$\begin{array}{c}\text { Rate } \\
(\mathrm{kg} / \mathrm{ha})\end{array}$} & \multicolumn{8}{c}{ months after application* } \\
\cline { 3 - 8 } & 1 & 2 & 3 & 4 & 5 & 6 & 7 & 9 \\
\hline alachlor & & & & & & & & \\
1.7 & 64 & & & & & & & \\
3.3 & 46 & 61 & 74 & & & & & \\
6.6 & 21 & 35 & 56 & 77 & & & & \\
& & & & & & & & \\
metolachlor & & & & & & & & \\
1.7 & 24 & 28 & 34 & 61 & & & & \\
3.3 & 9 & 13 & 17 & 31 & 59 & 74 & & \\
6.6 & 0 & 0 & 5 & 12 & 26 & 48 & 65 & \\
\hline
\end{tabular}

* Figures in this table are all significantly different from their respective controls $(=100), P<0.05$, pooled $\mathrm{SE} \pm 5.8$. Blank spaces indicate that no significant differences were recorded in that month. 
Herbicidal injury, as reflected by the morphological aberrations of German millet plants growing in the soil treated with alachlor and metolachlor, was much more severe than the reduction in dry weight. Generally some morphological aberrations could be noticed for at least 1 Generally some significant reductions in dry matter ceased to occur from herbicide residues. However, in such cases the seedlings recovered in 2-3 weeks and normal plant growth (and dry matter) was produced afterwards.

In the case of the proprietary mixture of atrazine + metolachlor it was possible to separate the phytotoxic effects of the two herbicides. wetolachlor resulted in early damage to the emerging seedlings of oats and German millet which comprised morphological aberrations and growth stunting. Atrazine damage, on the other hand was not visible until 2-3 weeks after germination and was characterised by chlorosis and death of developed leaves. Damage to German millet from the mixture was proportional to the rate of metolachlor as this species is relatively tolerant to atrazine. However, damage to oats, as measured by the dry weight, was to atrazine. How ever, damage to statistically similar to the total damage caused by the same rates of two herbicides applied separately. It is clear, therefore, that with mixtures where both components have relatively long residual life, extra care would have to be taken in selecting the subsequent crops in rotation as some species could be susceptible to both chemicals, as is the case with oats in this instance.

The residual activity of all four herbicides varied only slightly between the 2 years and the differences were not significant in any case. This is not surprising as the differences between the total rainfall $(361 \mathrm{~mm}$ in 1976-77 and $321 \mathrm{~mm}$ in 1977-78 during the first 5 months of the trials) and the two soils were not great. The Horotiu soil had a higher organic matter content than the Hamilton soil but the latter had twice the clay matter contente 1). As both the organic matter and clay fractions are known to influence herbicide adsorption and phytotoxicity (Adams 1973; Rahman 1977; Weber and Weed 1974), the overall adsorptive capacity of the two soils may not differ appreciably.

Results from this study show that it is possible to select herbicides for maize which could provide both broadleaf and grass weed control for different lengths of time by virtue of the differences in their residual life. In addition to the herbicides mentioned here, a few other herbicides are available for control of weeds in maize. Thus depending upon the spectrum of weeds, length of time for which weed control is required and the crop to follow in rotation a grower may choose the appropriate herbicide to fulfill his requirements.

\section{ACKNOWLEDGEMENTS}

Thanks are due to Ruakura Soil Testing Laboratory for soil analyses and to Ciba-Geigy (N.Z.) for providing the metolachlor.

\section{REFERENCES}

Adams, R. S. Jr., 1973. Factors influencing soil adsorption and bioactivity of pesticides. Residue Rev., 47: 1-54.

Burnside, O. C., 1976. Soil persistence of corn herbicides during the year of application. Proc. North Central Weed Control Conf., 33: 10-12.

Hadd ow, B. C., 1977. Bladex: a versatile multi-crop herbicide. Span, 20: 133-135.

Naish, R. W. and Forgie, C. D., 1976. Atrazine residues under commercial maize cropping conditions. Proc. 29th N.Z. Weed and Pest Control Conf.: 120-123. 


\section{Crop Weeds}

Rahman, A., 1977. Persistence of terbacil and trifluralin under different soil and climatic conditions. Weed Res., 17: 145-152.

Rahman, A. and Brown, N. S., 1977. Atrazine residues in the Gisborne Plains and Waikato regions. Proc. 30th N.Z. Weed and Pest Control Conf.: 19-24

Rahman, A. and Cox, T. I., 1975. Bioassay techniques for the determination of herbicide residues. Proc. 28th N.Z. Weed and Pest Control Conf.: 96-100.

Rowe, G. R., O'Connor, B. P. and Patterson, T. M., 1976. Metolachlor for control of 'summer grasses' in maize. Proc. 29 th N.Z. Weed and Pest Control Conf.: 135-137.

Sirons, G. J., Frank, R. and Sawyer, T., 1973. Residues of atrazine, cyanazine and their phytotoxic metabolites in a clay loam soil. $J$. Agr. Food Chem., 21: 1016-1020.

Weber, J. B. and Weed, S. B., 1974. Effects of soil on the biological activity of pesticides. In "Pesticides in soil and water". W. D. Guenzi (Ed.). Soil Sci. Soc. Amer. Inc., Madison, Wisconsin. 